\title{
Przedsiębiorczość Polski Wschodniej - ocena potencjału rozwojowego z wykorzystaniem analizy porównawczej
}

\author{
Entrepreneurship in Eastern Poland - the evaluation of development \\ potential using comparative analysis
}

\begin{abstract}
Streszczenie
Wciąż zmieniające się warunki funkcjonowania systemów gospodarczych zwiększają presję na skuteczne zarządzanie procesem ich rozwoju. Dotyczy to zarówno poziomu operacyjnego, jak i strategicznego. Nie można zapominać, że podstawą każdego podejmowania decyzji jest dostęp do odpowiednio przygotowanej informacji zarządczej, pozwalającej na prawidłowe wyznaczenie celów oraz ocenę stopnia ich realizacji. Celem artykułu jest przedstawienie modelowego opisu przedsiębiorczości, jako jednego z wymiarów analizy strategicznej, odnoszącego się do potencjału systemu gospodarczego. W tekście opisano konstrukcję modelu oraz zależności między jego poszczególnymi elementami. Przedstawiono także przykład analizy przedsiębiorczości, porównując regiony Polski Wschodniej. Postawiono tutaj następujące pytanie badawcze: Który region Polski Wschodniej charakteryzuje się najwyższym potencjałem przedsiębiorczym?.

Wskazany wyżej wymiar opisano w artykule z perspektywy bardziej złożonego układu elementów potencjału rozwojowego, obejmujących potencjał gospodarki, społeczeństwa i środowiska. Zaproponowano sposób pomiaru poziomu przedsiębiorczości za pomocą wybranych mierników opartych na statystyce GUS. Użyto ich do oceny porównawczej, a więc z wykorzystaniem idei benchmarkingu. Dzięki temu możliwe jest określenie, na ile dany wymiar stanowi mocną bądź słabą stronę wskazanego systemu.

Analizę przeprowadzono na przykładzie województw należących do tzw. Polski Wschodniej. Obszar ten charakteryzuje się peryferyjnością terytorialną oraz rozwojową. Dzięki temu stanowi ciekawy przykład do analiz procesów rozwojowych. Sytuację województw przedstawiono na tle pozostałych regionów w kraju. Szczególną uwagę zwrócono jednak na ich sytuację w kontekście potencjału województw: mazowieckiego, małopolskiego i pomorskiego. Są to regiony, w których funkcjonują dość prężne układy metropolitalne, znacząco oddziałujące na mobilne elementy potencjału Polski Wschodniej, w szczególności na kapitał ludzki oraz inwestycyjny.
\end{abstract}

\footnotetext{
Abstract

Changing conditions of the operation of economic systems increase the pressure on the effective management of their developmental process. This applies to both the strategic and operational management level. The basis for decision-making is access to appropriately prepared management information, allowing for the correct determination of objectives and the assessment of the degree of their implementation. The aim of the article is to present a model description of entrepreneurship as one of the dimensions of strategic analysis relating to the potential of the economic system. It also explains the structure of the model and interdependencies between the individual elements thereof. Presented additionally is an example of the analysis of entrepreneurship comparing the regions of Eastern Poland.
} 
The measurement indicated above is described in the article from the perspective of the more complex elements of development potential, covering the potential of the economy, society and the environment. A method has been proposed for measuring enterprise level using selected measures based on statistics from the Central Statistical Office. These were used in the comparative analysis, thus employing the idea of benchmarking. This makes it possible to determine how the given dimension is a strong or weak side of the system.

The analysis was carried out using the example of the voivodeships belonging to so-called Eastern Poland. This area is characterised by territorial and developmental suburbanness. Owing to this, it constitutes an interesting example for the analysis of developmental processes. The situation of the voivodships has been presented against the background of the other regions in the country. Particular attention, however, has been paid to their situation in the context of the potential of the Mazovian, Malopolskie and Pomorskie voivodeships. These are regions in which relatively vibrant Metropolitan systems operate, significantly affecting the mobile elements of the potential of Eastern Poland, in particular, human and investment capital.

Słowa kluczowe: benchmarking; Polska Wschodnia; potencjał rozwojowy; przedsiębiorczość Keywords: benchmarking; development potential; Eastern Poland; entrepreneurship

\section{Wstęp}

Analizując sytuację danego systemu gospodarczego, warto w pierwszej kolejności zwrócić uwagę na jego ewentualne mocne i słabe strony (Pickton, Wright, 1998; Gieryszewska, Romanowska, 1998). Opis potencjału daje takie możliwości, tworząc podstawę do identyfikacji głównych kierunków specjalizacji danego terytorium. Dzięki identyfikacji mocnych stron dany region może skoncentrować się na ich rozwijaniu (Porter, 1990; McCann, Ortega-Argilés, 2013). Takie podejście daje szansę zbudowania odpowiedniego wizerunku w skali międzynarodowej, a nawet globalnej. Pozwala to na selektywne przyciąganie kapitału inwestycyjnego, a w konsekwencji wykreowanie przyśpieszonych ścieżek rozwoju i wzrostu gospodarczego w globalnej ekonomii (Rusu, 2013). Tego typu, inteligentna specjalizacja jest niezwykłą szansą, szczególnie dla regionów o słabszym wyjściowym potencjale gospodarczym.

W artykule przedstawiono także teoretyczne założenia dotyczące schematu opisu potencjału endogenicznego. Szczególną uwagę zwrócono na wymiar potencjału przedsiębiorczego. Zaprezentowano możliwości dokonania analizy porównawczej w celu uzyskania diagnozy, czy w przyjętym zbiorze porównawczym (benchmarków) dany region może zaliczyć ten wymiar do mocnych czy też do słabych stron. Postawiono tutaj następujące pytanie badawcze: PG. Czy przedsiębiorczość stanowi mocna czy słaba stronę porównywanych regionów?. Doprecyzowując pytanie główne, wskazano następujące pytania szczegółowe:

- PS.1. Jak zmierzyć potencjat przedsiębiorczy regionu?,

- PS.2. Czy w badanych regionach dominuja pozytywne czy negatywne trendy rozwoju przedsiębiorczości w kontekście zmian w obszarach stanowiących benchmark?,

- PS.3. Czy badane regiony charakteryzuja się spójnymi trendami, czy też wykazuja znaczne ich zróżnicowanie?.

Jako obszar badań wybrano Polskę Wschodnią. W artykule przyjęto, że określenie Polska Wschodnia odnosi się do terenu objętego wsparciem Programu Operacyjnego Rozwój Polski Wschodniej. W jego skład wchodzą województwa: lubelskie, podkarpackie, podlaskie, świętokrzyskie i warmińsko-mazurskie. W literaturze niekiedy wykorzystuje się także pojęcie ściana wschodnia, które jednak odnosi się do nieco innego obszaru, obejmującego województwa położone bezpośrednio przy wschodniej granicy Polski, czyli: podkarpackie, lubelskie i podlaskie 
(Gorzelak, 2007). Niekiedy dodaje się tutaj również wschodnie powiaty województwa mazowieckiego. Wybór obszaru analizy wydaje się jednak słuszny ze względu na politykę interwencji państwa prowadzoną za pomocą programów operacyjnych. Taka sytuacja oznacza, że uzasadnione jest analizowanie sytuacji pięciu wymienionych województw w sposób spójny i zorganizowany, zwłaszcza w kontekście Strategii rozwoju społeczno-gospodarczego Polski Wschodniej do roku 2020 (Rada Ministrów, 2008).

Mimo wielu wspólnych cech, wspomniane regiony mają oczywiście własną specyfikę i różnią się pod względem możliwości specjalizacji. Uzasadnione zatem wydaje się opisywanie Polski Wschodniej z uwzględnieniem poszczególnych województw, a nie jako jednego obszaru. Stąd też przyjęto taki sposób prezentacji danych, który umożliwia analizę interregionalną (porównanie Polski Wschodniej i pozostałych regionów) oraz intraregionalną (porównanie województw w ramach Polski Wschodniej).

Bardzo ważnym elementem proponowanej analizy jest wykorzystanie spójnego podejścia opartego na metodzie benchmarkingu. Wprowadzona analiza porównawcza stanowi ważną część tej metody. Stwarza też możliwość identyfikacji słabych i mocnych stron badanego regionu w kontekście cech innych systemów gospodarczych, traktowanych jako punkt odniesienia. Prezentowanej analizie poddano wszystkie województwa w kraju. Jednak szczególną uwagę zwrócono na województwa mazowieckie, małopolskie oraz pomorskie. Stanowią one główne zagrożenie dla polityk rozwojowych na poziomie całej Polski Wschodniej oraz poszczególnych województw. Intensywne procesy rozwojowe zachodzące w głównych miastach tych regionów powodują znaczny drenaż kapitału mobilnego, a więc przede wszystkim ludzkiego i inwestycyjnego.

Planując rozwój terenów o słabszym poziomie rozwoju, należy zwrócić uwagę na możliwości wygenerowania dodatkowej aktywności ludzi, opierając się na regionalnym potencjale przedsiębiorczym. Ten wymiar potencjału trzeba traktować jako główny czynnik rozwojowy, przekładający się na inne elementy gospodarki. Dlatego też, opisując w niniejszym artykule podejście oparte na modelu potencjału rozwojowego oraz analizie porównawczej, skupiono się właśnie na potencjale przedsiębiorczym.

\section{Przedsiębiorczość i inne wymiary potencjału rozwojowego - model analizy porównawczej} Model analizy porównawczej potencjału rozwojowego jest elementem szerszego podejścia do analizy strategicznej. Ujęcie proponowane przez autora artykułu obejmuje pewien schemat analizy, użyteczny w fazie programowania i controllingu strategii. Jego warianty dostosowane są do cech samorządu terytorialnego poszczególnych szczebli, a więc województw, powiatów i gmin. Ocena sytuacji w zakresie potencjału rozwojowego pozwala na podjęcie decyzji w sprawie priorytetów rozwojowych w odniesieniu do każdego z obszarów potencjału.

Warto podkreślić, że analiza potencjału endogenicznego - zwłaszcza w kontekście problematyki wzrostu gospodarczego - ma bardzo mocny fundament w teorii ekonomii. Opisane są w niej liczne endogeniczne koncepcje wzrostu, które wyjaśniają kompleksowo lub częściowo proces rozwoju gospodarczego. Część z nich to tzw. koncepcje endogeniczne, poszukujące uzasadnienia procesów rozwojowych w czynnikach endogenicznych. Wymienić tutaj można modele Romera, Lucasa, Rebello oraz Aghiona i Howitta, tworzące tzw. nową teorię wzrostu (Churski, 2004; Aghion, Howitt, 1998).

Jednak zdecydowanie bardziej inspiracją do analizy porównawczej regionów jest podejście rynkowe prezentowane przez Portera. Należy zatem uwzględniać takie parametry potencjału endogenicznego, które warunkują zdolności gospodarek do konkurowania na rynkach dóbr, usług i kapitału. Porter szczególnie zwraca uwagę na czynniki dotyczące produktywności, 
inwestycji oraz zasoby siły roboczej (1990). W globalnym otoczeniu odpowiednie kształtowanie potencjału endogenicznego to podstawowy element procesu konkurowania jednostek terytorialnych na rynkach kapitału mobilnego (kapitał ludzki, kapitał inwestycyjny) czy rynkach turystycznych (Strojny, 2012).

Badając potencjał endogeniczny, należy się odnieść do dostępnego zasobu danych statystycznych oraz zbudować na ich podstawie zasób informacji zarządczej. Jednym z przykładów takiego podejścia jest indeks RCI - Regional Competitiveness Index (Annoni, Dijkastra, 2013). Wykorzystuje on trzy najważniejsze wymiary: indeksy podstawowe, indeksy efektywności oraz indeksy innowacyjności, podzielone na bardziej szczegółowe grupy zmiennych. Na ich podstawie przygotowuje się analizę poziomu konkurencyjności regionów w Unii Europejskiej.

Analizując potencjał rozwojowy, warto zatem wykorzystać podejście pozwalające na wyodrębnienie jego poszczególnych elementów. Autor artykułu proponuje tutaj przyjęcie modelu zawierającego osiem wymiarów przedstawionych na ryc. 1. Można je pogrupować w ramach trzech podstawowych obszarów, charakteryzujących system gospodarczy, wyróżniając: (1) potencjał społeczeństwa, (2) potencjał gospodarki, (3) potencjał środowiska. Co do zasady tworzenia, jest on zbliżony do modelu RCI, choć proponuje się nieco inny przekrój danych statystycznych.

Ryc. 1. Model potencjału rozwojowego systemów gospodarczych

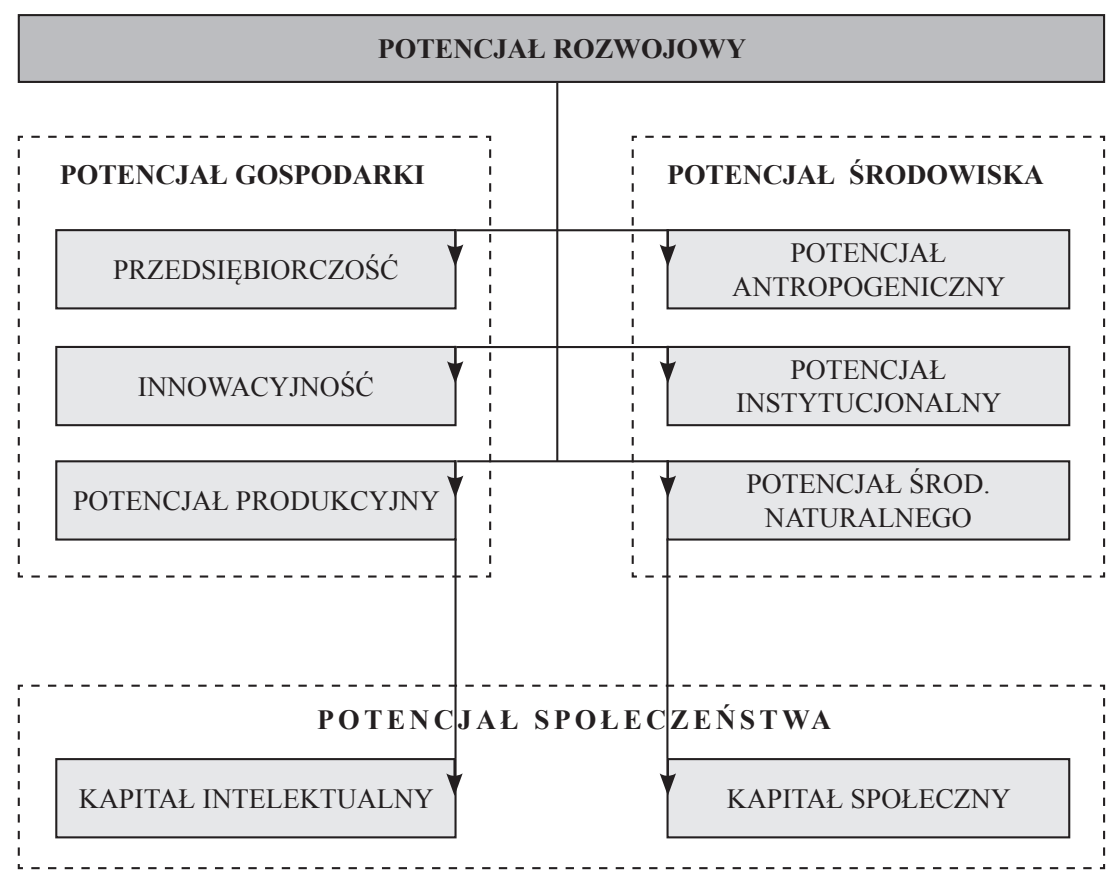

Źródło: opracowanie własne.

W ramach pierwszego z wymienionych obszarów wyróżniono kapitał intelektualny oraz kapitał społeczny. Pierwszy z nich może być rozumiany jako ,wiedza, zdolności, kompetencje oraz cechy ucieleśnione w jednostkach, które ułatwiają kreowanie osobistego, społecznego oraz ekonomicznego dobrobytu” (Keeley, 2007). Natomiast kapitał społeczny obejmuje „obywatelskie nastawienie członków społeczeństwa, normy społeczne wspierające działania wspólne oraz zaufanie interpersonalne i zaufanie obywateli do instytucji publicznych" (Czapiński, 2011). 
W ramach potencjału gospodarki wyróżniono trzy podstawowe wymiary: przedsiębiorczość, innowacyjność oraz potencjał produkcyjny. Pierwszy z nich może być traktowany jako energia ludzka przejawiająca się w inicjowaniu przedsięwzięć gospodarczych (Timmons, 1986). Z kolei innowacyjność ,,polega na wytworzeniu i wprowadzeniu do sprzedaży, a tym samym do użytku nowego produktu, albo na gospodarczym zastosowaniu nowego procesu otrzymywania znanych już wcześniej produktów" (Czupiał, 1994). Natomiast potencjał produkcyjny obejmuje te cechy systemu gospodarczego, które przekładają się na możliwość wytworzenia różnego rodzaju dóbr: usług, produktów przemysłowych, płodów i produktów rolnych itd.

Trzeci obszar potencjału przedsiębiorczego odnosi się do środowiska i dotyczy: potencjału antropologicznego, środowiska naturalnego oraz instytucjonalnego. Pierwszy z nich obejmuje wytwory pracy ludzkiej, w szczególności poziom urbanizacji i nasycenie różnego rodzaju infrastrukturą (Chądzyński i in., 2007). Oczywiście potencjał antropologiczny warunkowany jest stanem środowiska przyrodniczego (Burchard-Dziubińska, 2007). Tworzą one warunki do osiedlania się ludzi oraz możliwości powstawania miast. Ponadto w wielu wypadkach specyfika bogactw naturalnych wpływa na strukturę branżową gospodarki, a więc możliwości rozwoju przedsiębiorstw o określonym profilu działalności. Uzupełnieniem wymienionych elementów jest potencjał instytucjonalny (Chądzyński i in., 2007), który w niniejszym modelu utożsamiany jest głównie ze sprawnością administracji publicznej.

W artykule skupiono się na analizie tylko jednego z wymienionych ośmiu wymiarów, a więc na potencjale przedsiębiorczym. Zaprezentowano sposób jego pomiaru z wykorzystaniem sześciu mierników. W tab. 1. przedstawiono ich krótką charakterystykę, obejmującą nazwę miernika oraz sposób jego wyliczania na podstawie zmiennych dostarczanych przez statystykę publiczną (GUS).

Tab. 1. Mierniki potencjału przedsiębiorczego

\begin{tabular}{|c|c|}
\hline Lp. & Miernik \\
\hline \multirow[b]{2}{*}{ Z1. } & Liczba osób fizycznych prowadzących działalność gospodarczą na 1000 mieszkańców \\
\hline & $\begin{array}{l}\text { Wskaźnik liczony jest na podstawie iloczynu: } \\
\text { osoby fizyczne prowadzące działalność gospodarczą / ludność ogółem *1000 }\end{array}$ \\
\hline \multirow[b]{2}{*}{$\mathrm{Z} 2}$. & Udział spółek handlowych w podmiotach gospodarki narodowej sektora prywatnego \\
\hline & $\begin{array}{l}\text { Wskaźnik liczony jest na podstawie iloczynu: } \\
\text { sektor prywatny - spółki handlowe / sektor prywatny - sektor prywatny - ogółem *100\% }\end{array}$ \\
\hline \multirow[b]{2}{*}{ Z3. } & Liczba podmiotów z udziałem kapitału zagranicznego na 1000 mieszkańców \\
\hline & $\begin{array}{c}\text { Wskaźnik liczony jest na podstawie iloczynu: } \\
\text { sektor prywatny - spółki handlowe z udziałem kapitału zagranicznego / ludność ogółem } \\
* 1000\end{array}$ \\
\hline \multirow[b]{2}{*}{ Z4. } & Udział firm średnich w ogólnej liczbie podmiotów gospodarki narodowej sektora prywatnego \\
\hline & $\begin{array}{c}\text { Wskaźnik liczony jest na podstawie iloczynu: } \\
\text { (jednostki gospodarcze } 10-49+\text { jednostki gospodarcze } 50-250) / \text { jednostki gospodarcze } \\
\text { ogółem *100\% }\end{array}$ \\
\hline \multirow[b]{2}{*}{ Z5. } & Wartość nakładów inwestycyjnych w sektorze MŚP na 1 podmiot MŚP \\
\hline & $\begin{array}{c}\text { Wskaźnik liczony jest na podstawie iloczynu: } \\
\text { (nakłady inwestycyjne małych firm + nakłady inwestycyjne średnich firm) / (jednostki } \\
\text { gospodarcze } 10-49+\text { jednostki gospodarcze } 50-250)\end{array}$ \\
\hline \multirow{2}{*}{ Z6. } & Wartość współczynnika aktywności zawodowej w grupie osób w wieku produkcyjnym \\
\hline & Współczynnik aktywności zawodowej \\
\hline
\end{tabular}

Źródło: opracowanie własne. 
Wybrane dane poddano analizie z wykorzystaniem określonych narzędzi, takich jak: (1) indeksy jednopodstawowe, (2) standaryzacja danych. Indeksy jednopodstawowe wyliczono dla roku bazowego $\mathrm{y}_{0}=1999^{1}$. Zastosowano tutaj wzór 1 .

$$
\mathrm{I}_{\mathrm{t}}=\frac{\mathrm{V}_{\mathrm{t}}}{\mathrm{V}_{\mathrm{t} 0}}
$$

gdzie:

$\mathrm{I}_{\mathrm{t}} \quad$ - wartość indeksu jednopodstawowego

$\mathrm{V}_{\mathrm{t}}$ - wartość zmiennej pierwotnej w roku $\mathrm{t}$

$\mathrm{V}_{\mathrm{t} 0}$ - wartość zmiennej pierwotnej w roku bazowym t0

Do oceny porównawczej wykorzystano natomiast metodę unitaryzacji zerojedynkowej. Wyliczając na podstawie zmiennych pierwotnych wartości standaryzowane, posłużono się wzorem 2a-2d.

Dla stymulant: $\quad \mathrm{S}_{\mathrm{it}}=\frac{\mathrm{V}_{\mathrm{it}}-\mathrm{V}_{\min t}}{\mathrm{~V}_{\operatorname{maxt}}-\mathrm{V}_{\min }}$

Dla destymulant: $\quad \mathrm{S}_{\mathrm{it}}=\frac{\mathrm{V}_{\operatorname{maxt}}-\mathrm{V}_{\text {it }}}{\mathrm{V}_{\operatorname{maxt}}-\mathrm{V}_{\min }}$

$$
\begin{aligned}
A K_{i t} & =\frac{\sum_{i=1}^{n} S_{i t}}{n} \\
A G_{i t} & =\frac{\sum_{i=1}^{n} A K_{i t}}{n}
\end{aligned}
$$

gdzie:

$\mathrm{S}_{\mathrm{it}} \quad$ - wartość standaryzowana zmiennej $\mathrm{V}$ w jednostce terytorialnej i oraz czasie $\mathrm{t}$

$\mathrm{V}_{\text {it }} \quad$ - wartość zmiennej pierwotnej w jednostce terytorialnej i oraz czasie $\mathrm{t}$

$\mathrm{V}_{\text {mint }}$ - wartość minimalna zmiennej $\mathrm{w}$ grupie porównywanych jednostek terytorialnych $\mathrm{w}$ czasie $\mathrm{t}$

$\mathrm{V}_{\text {maxt }}$ - wartość maksymalna zmiennej $\mathrm{w}$ grupie porównywanych jednostek terytorialnych w czasie $\mathrm{t}$

$\mathrm{AK}_{\mathrm{it}}$ - zagregowany wskaźnik pozycji konkurencyjnej jednostki terytorialnej i w czasie t na poziomie kryterium AHP opisującego dany wymiar potencjału endogenicznego

$\mathrm{AG}_{\mathrm{it}}$ - zagregowany wskaźnik pozycji konkurencyjnej jednostki terytorialnej i w czasie t na poziomie ogólnym opisującym potencjał endogenicznego

Analizę danych przeprowadzono w dwóch wymiarach. Pierwszy z nich to porównanie sytuacji danego regionu w odniesieniu do innych, traktowanych jako porównawcze (benchmarki). Natomiast drugi wymiar dotyczy trendów obserwowanych w odniesieniu do poszczególnych zmiennych w czasie. W taki właśnie sposób przeprowadzono analizę w kolejnym punkcie artykułu.

\footnotetext{
${ }^{1}$ W 1999 r. uruchomiono trójstopniowy podział terytorialny kraju. W przypadku, gdy jakaś zmienna została później udostępniona w systemie statystyki publicznej, jako okres bazowy zastosowano pierwszy rok udostępnienia zmienne.
} 


\section{Analiza porównawcza potencjału przedsiębiorczego Polski Wschodniej}

Pierwszy z wymienionych wyżej mierników przedsiębiorczości odnosi się do liczby osób fizycznych prowadzących działalność gospodarczą. Proponuje się budowę wskaźnika odnoszącego tę zmienną do liczby mieszkańców. Dzięki temu uzyskuje się informację o nasyceniu postaw przedsiębiorczych w społeczeństwie. Najprostsza forma organizacyjno-prawna jest wciąż najbardziej popularnym sposobem prowadzenia działalności gospodarczej. Przyjąć zatem należy, że im bardziej w danym społeczeństwie osoby są skłonne otwierać tego typu działalność gospodarczą, tym wyższy jest poziom przedsiębiorczości.

Wartość omawianego wskaźnika kształtowała się w Polsce w 2013 r. w przedziale między 56,8 a 95,5. Można zatem powiedzieć, że skłonność do zakładania własnej działalności gospodarczej znacznie różnicuje poszczególne regiony. Województwa Polski Wschodniej wypadają pod tym względem najsłabiej w kraju, przy czym najtrudniejsza sytuacja występuje na Podkarpaciu (ryc. 2).

Ryc. 2. Osoby fizyczne prowadzące działalność gospodarczą na 1 tys. mieszkańców (Z1) - Polska Wschodnia na tle kraju w $2013 \mathrm{r}$.

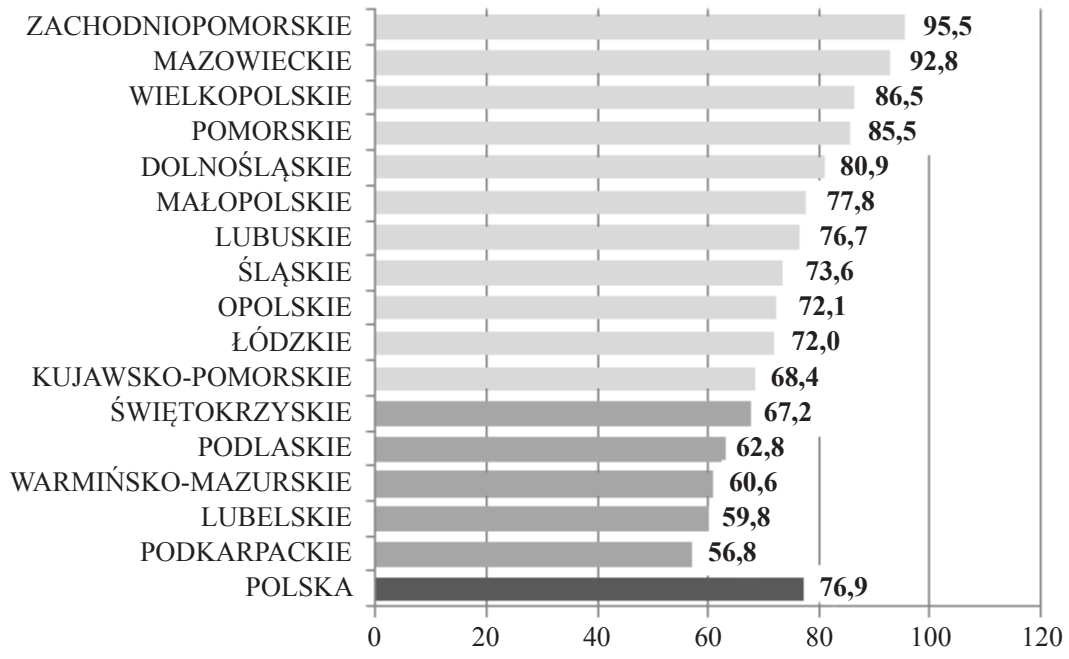

Źródło: opracowanie własne na podstawie GUS.

Dość istotne dla oceny sytuacji jest także określenie trendów dotyczących omawianego wskaźnika na przestrzeni ostatnich lat. Przyjmując perspektywę od 1999 r., można stwierdzić, że w większości przypadków dystans rozwojowy pomiędzy województwami Polski Wschodniej a bardziej rozwiniętymi województwami w kraju się zwiększa (ryc. 3). Szczególnie dotyczy to województw podlaskiego, warmińsko-mazurskiego oraz podkarpackiego. Udział przedsiębiorstw osób fizycznych zlokalizowanych w tych województwach w odniesieniu do ich liczby w kraju spadł o kilka procent. Nawet województwo świętokrzyskie, które najlepiej wypada wśród badanych regionów w ostatnich kilku latach (od 2006 r.), odnotowuje znaczące pogarszanie się sytuacji. 
Ryc. 3. Zmiana liczby osób fizycznych prowadzących działalność gospodarczą w województwach Polski Wschodniej w stosunku do kraju (rok bazowy: 1999)

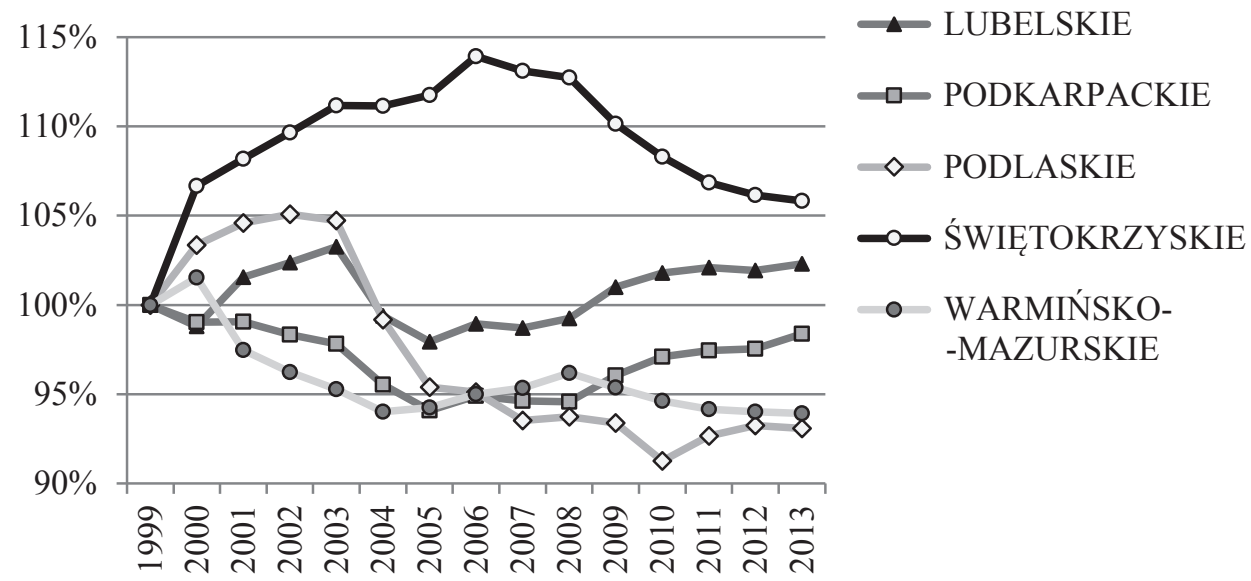

Źródło: opracowanie własne na podstawie GUS.

Drugi miernik przedsiębiorczości odnosi się do udziału spółek handlowych w ogólnej liczbie podmiotów sektora prywatnego. Przyjęto, że tego typu przedsiębiorstwa są bardziej stabilne oraz zapewniają wyższą jakość zarządzania. Dzięki temu tworzą podstawę do budowania klasy średniej, której istnienie jest niezwykle istotne z punktu widzenia rozwoju przedsiębiorczości w danym społeczeństwie.

Analizując sytuację województw Polski Wschodniej na tle kraju, warto podkreślić, że charakteryzują się one najniższym odsetkiem spółek handlowych. Wynosi on od 5,16\% w województwie świętokrzyskim do 6,39\% w województwie lubelskim (ryc. 4). Inne, lepiej rozwinięte regiony charakteryzują się zdecydowanie wyższą wartością wskaźnika. W Mazowieckim wynosi on ponad 16\%, na Pomorzu prawie 10\%, zaś na Dolnym Śląsku i w Wielkopolsce - ponad 9\%.

Ryc. 4. Udział spółek handlowych w podmiotach sektora prywatnego ogółem (Z2) - województwa Polski Wschodniej na tle kraju w 2013 r.

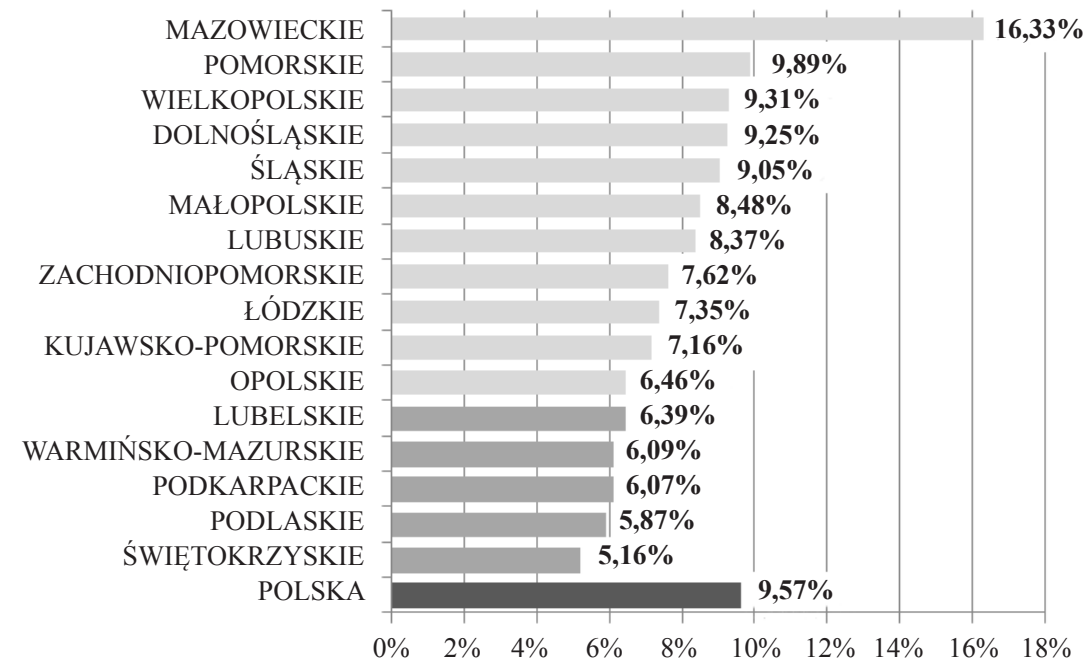

Źródło: opracowanie własne na podstawie GUS. 
Atrakcyjność inwestycyjna dużych miast powoduje, że regionom peryferyjnym trudno jest utrzymać konkurencyjność. Skutkuje to stopniowym przenoszeniem siedzib już istniejących spółek do większych miast. Częściej powstają tam także nowe podmioty. W latach 1999-2013 obserwuje się więc stopniowe pogarszanie się konkurencyjności większości województw Polski Wschodniej. Udział liczby zlokalizowanych tam przedsiębiorstw w ogólnej liczbie podmiotów w kraju stopniowo spada, osiągając poziom od 86\% do 96\% stanu z roku bazowego. Jedynym wyjątkiem jest województwo podkarpackie, w którym liczba spółek handlowych zwiększała się szybciej niż w kraju (ryc. 5).

Ryc. 5. Zmiana udziału spółek handlowych w podmiotach sektora prywatnego w województwach Polski Wschodniej w stosunku do kraju (rok bazowy: 1999)
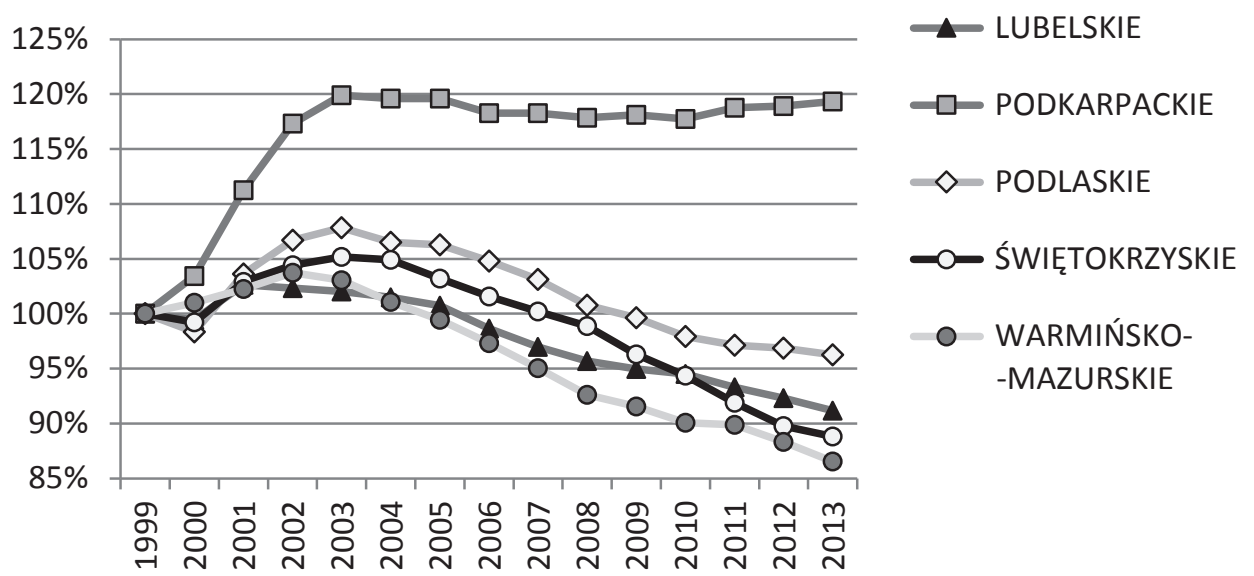

Źródło: opracowanie własne na podstawie GUS.

Bardzo ważną determinantą rozwoju regionów jest aktywność podmiotów z udziałem kapitału zagranicznego. Wzmacniają one miejscowy potencjał rozwojowy, aktywizując działalność innowacyjną oraz zwiększając moce produkcyjne. Wiele tego typu podmiotów tworzy także sieć współpracy z lokalnym sektorem MŚP, dając podstawy rozwoju przedsiębiorczości. W badaniu przyjęto zatem, że liczba tego typu podmiotów, przypadająca na każdy tys. mieszkańców, jest istotnym miernikiem potencjału przedsiębiorczego (ryc. 6).

Potencjał Polski Wschodniej, mierzony omawianym wskaźnikiem, należy ocenić jako relatywnie słaby. W badanych regionach na tys. mieszkańców przypada od 0,48 do 0,71 firmy z udziałem kapitału zagranicznego. Na Mazowszu wskaźnik jest dziesięciokrotnie wyższy i wynosi 5,81. Warto podkreślić wysoką pozycję regionów o relatywnie słabym poziomie rozwoju, które położone są w przy zachodniej granicy. Chodzi tutaj o województwa zachodniopomorskie oraz lubuskie, gdzie na tys. mieszkańców przypada odpowiednio 2,74 i 2,72 podmiotu z udziałem kapitału zagranicznego.

Sytuacja Polski Wschodniej pod względem omawianego wskaźnika zmieniała się w poszczególnych województwach w sposób dość zróżnicowany. Województwa warmińsko-mazurskie i świętokrzyskie od 1999 r. znacząco utraciły konkurencyjność względem kapitału zagranicznego. Skutkiem tego jest wzrost dystansu rozwojowego w porównaniu do regionów bardziej rozwiniętych. W stosunku do roku bazowego ich udział w ogólnej liczbie podmiotów z udziałem kapitału zagranicznego w kraju zmniejszył się do 80\%. 
Ryc. 6. Liczba spółek z udziałem kapitału zagranicznego na 1 tys. mieszkańców (Z3) - Polska Wschodnia na tle kraju w 2013 r.

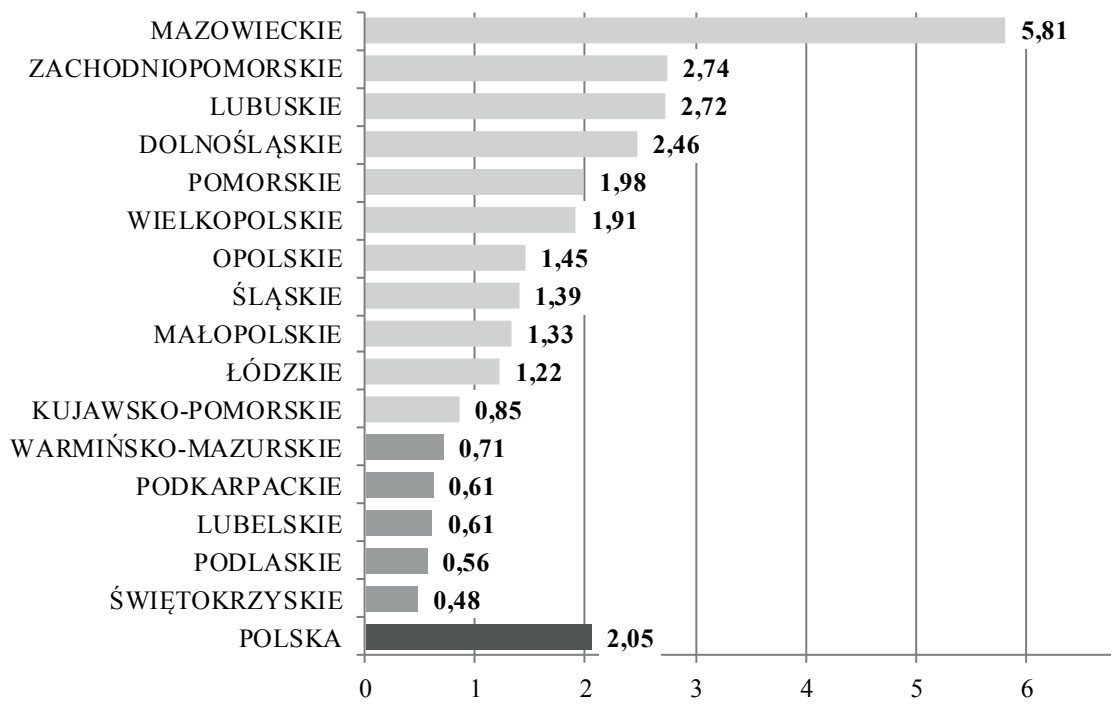

Źródło: opracowanie własne na podstawie GUS.

Podobnie jak w przypadku poprzedniego wskaźnika, również tutaj Podkarpacie wyróżnia się na tle pozostałych województw Polski Wschodniej. W latach 1999-2013 poprawiło swoją pozycję konkurencyjną, zwiększając udział w ogólnej liczbie przedsiębiorstw tworzonych z wykorzystaniem kapitału zagranicznego aż o 34\% (ryc. 7). Warto podkreślić, że w ostatnich latach obserwuje się dość dużą dynamikę w tym zakresie, co przekłada się również na ogólny poziom potencjału przedsiębiorczego. Pozytywne trendy obserwuje się od 2008 r. także w województwach podlaskim i lubelskim. Mają one jednak znacznie mniejsze natężenie.

Ryc. 7. Zmiana liczby spółek z udziałem kapitału zagranicznego na 1 tys. mieszkańców w województwach Polski Wschodniej w stosunku do kraju (rok bazowy: 1999)

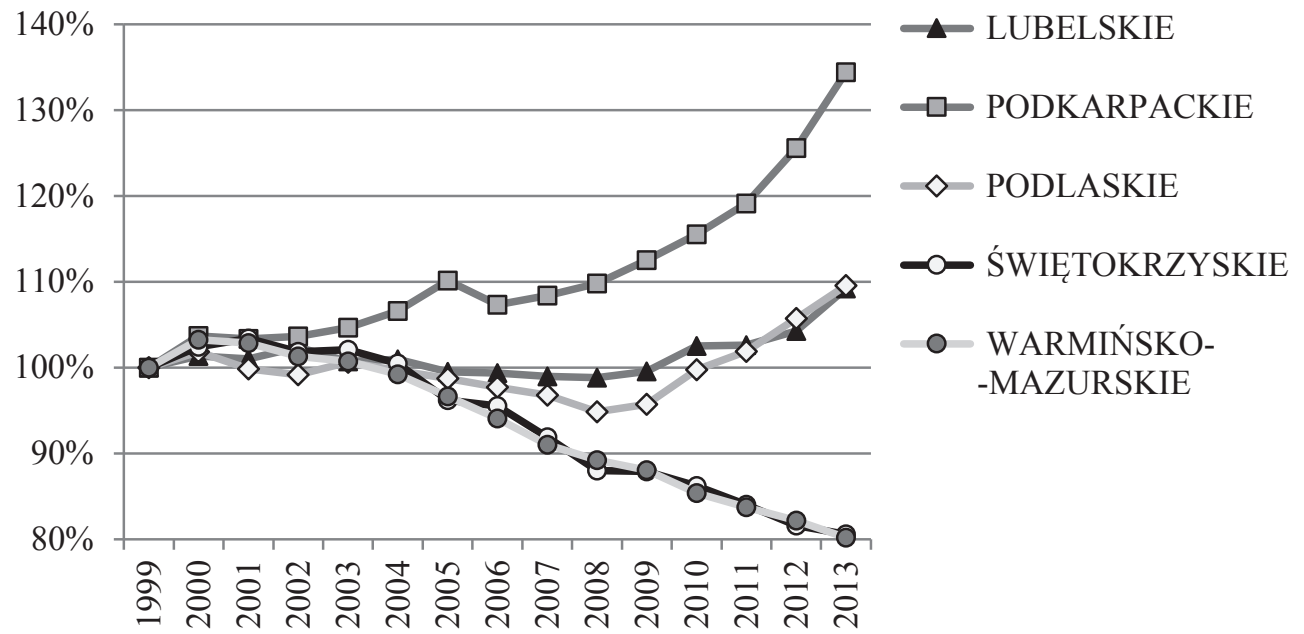

Źródło: opracowanie własne na podstawie GUS. 
W powszechnym odbiorze rozwój przedsiębiorczości utożsamia się z sytuacją sektora MŚP. Warto jednak podkreślić, że główny potencjał rozwojowy tworzą firmy małe i średnie. Mają one już wystarczającą skalę działalności do tego, aby angażować się w procesy innowacyjne. Firmy mikro najczęściej działają w prostych branżach i mają ograniczone możliwości angażowania w działania rozwojowe środków finansowych oraz pracowników. Siłą firm mikro jest ich zdolność do szybkiego dostosowywania się do sytuacji rynkowej przez przebranżowienie się. W niniejszym badaniu przyjęto, że szczególnym przejawem przedsiębiorczości jest relatywnie duży udział firm małych i średnich w ogólnej liczbie podmiotów z sektora MŚP. Odsetki tego typu podmiotów są niewielkie ze względu na dominację firm mikro (ryc. 8). Wahają się w poszczególnych regionach od 3,57\% na Dolnym Śląsku do 4,96\% na Śląsku. Sytuacja w województwach Polski Wschodniej jest zróżnicowana. Największy odsetek obserwuje się w województwie warmińsko-mazurskim: 4,56\%, zaś najmniejszy w podlaskim $-3,91 \%$.

Ryc. 8. Udział firm małych i średnich w ogólnej liczbie podmiotów gospodarki narodowej (Z4) - Polska Wschodnia na tle kraju w 2013 r.

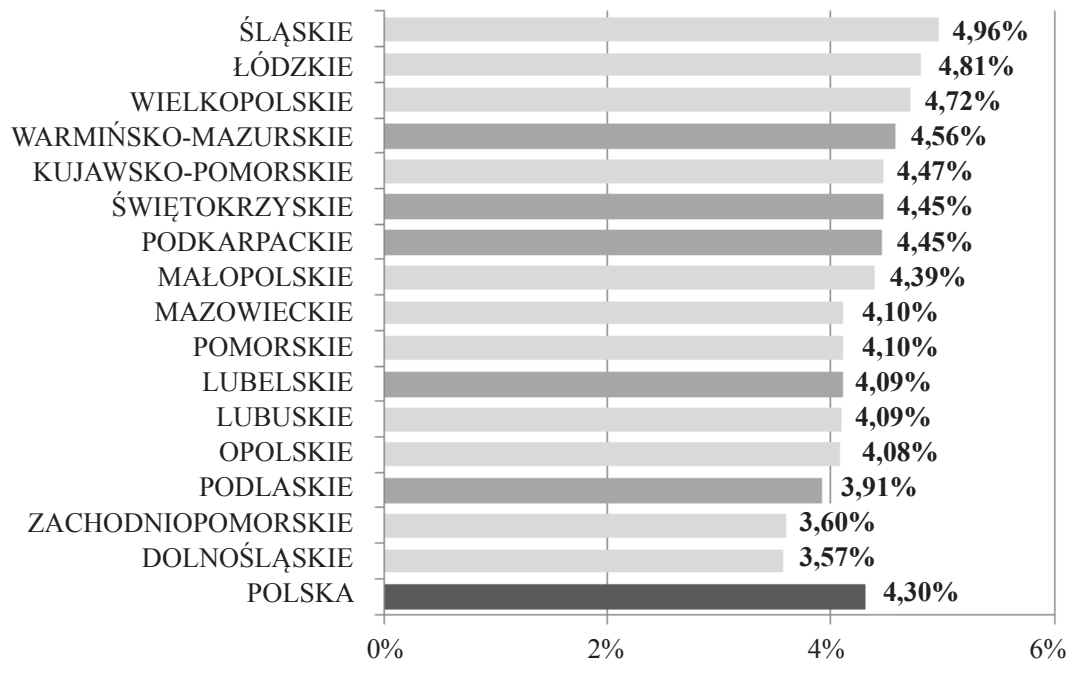

Źródło: opracowanie własne na podstawie GUS.

W latach 1999-2012 liczba małych i średnich przedsiębiorstw w Polsce rosła (ryc. 9). Jest to także widoczne w poszczególnych województwach. Warto jednak podkreślić, że na tle ogólnej liczby podmiotów udział badanej grupy maleje. Oznacza to, że ich przyrost jest słabszy niż pozostałych grup wyodrębnionych na podstawie kryterium wielkości zatrudnienia. W województwach Polski Wschodniej obserwuje się także słabnący potencjał przedsiębiorczości wyrażony opisywanym miernikiem. Udział firm małych i średnich w tych województwach w stosunku do liczby w kraju stopniowo maleje. W 2013 r. spadł w stosunku do roku 1999 o 4-9\%. Jedynie województwo świętokrzyskie nieznacznie poprawiło swoją sytuację na przestrzeni badanego okresu. 
Ryc. 9. Zmiana udziału firm małych i średnich w ogólnej liczbie podmiotów gospodarki narodowej w województwach Polski Wschodniej w stosunku do kraju (rok bazowy: 2002)

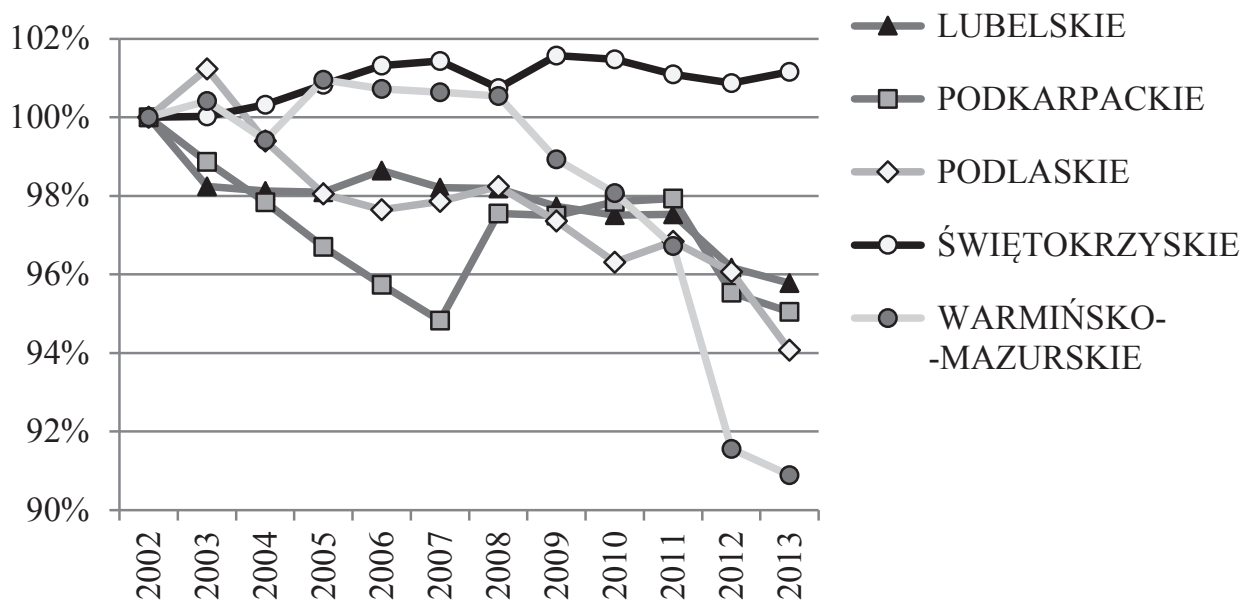

Źródło: opracowanie własne na podstawie GUS.

Oprócz liczby przedsiębiorstw z sektora MŚP ważna jest także ich aktywność. Może być ona mierzona w różny sposób, np. przez wartość wydatków inwestycyjnych. Oczywiście wpływają one na ważne elementy potencjału rozwojowego, jakimi są m.in. potencjał produkcyjny oraz innowacyjność. Dzięki inwestycjom w nowe technologie, budynki oraz inne elementy majątku rzeczowego firmy z sektora MŚP zyskują możliwość skuteczniejszego konkurowania. Wskaźnik pokazujący wartość wydatków przypadającą na 1 podmiot niesie dodatkową informację na temat skali działalności omawianych przedsiębiorstw. Warto podkreślić, że najważniejszym problemem polskich firm jest wciąż relatywnie słaby potencjał finansowy i produkcyjny. Pod tym względem znacząco ustępują one przedsiębiorstwom z krajów Europy Zachodniej, np. Niemiec. Tymczasem rosnący potencjał pozwala na wprowadzenie specjalizacji na stanowiskach pracy, tworzenie ścieżek kariery zawodowej oraz znacznie większy udział w pracach $\mathrm{B}+\mathrm{R}$, które stanowią fundament innowacyjności. Dlatego też w badaniu przyjęto, że im wyższy poziom nakładów inwestycyjnych przypadających na firmę, tym większy potencjał przedsiębiorczości. Głównie zwrócono uwagę na przedsiębiorstwa małe i średnie, które - jak stwierdzono wyżej stanowią najbardziej aktywną grupę podmiotów w sektorze MŚP.

Nakłady inwestycyjne omawianej grupy przedsiębiorstw są bardzo mocno zróżnicowane terytorialnie (ryc. 10). W 2012 r. kształtowały się od 183 tys. zł w województwie lubuskim do 389 tys. zł w województwie mazowieckim. Duże różnice dotyczą także województw Polski Wschodniej. Najwyższą wartość nakładów zanotowano w województwie podlaskim: 309 tys. zł, najniższą zaś w województwie warmińsko-mazurskim - 196 tys. zł.

Chęć do wydatkowania środków na inwestycje ma charakter koniunkturalny. Stąd też duże wahania tego typ wydatków w poszczególnych okresach. Udział województw Polski Wschodniej w ogólnej wartości kosztów poniesionych na inwestycje poprawia się jednak w większości wypadków. W najgorszej sytuacji jest województwo warmińsko-mazurskie, w którym obserwuje się spadek wskaźnika na przestrzeni lat. W pozostałych województwach, mimo wahań, sytuacja się poprawia. Stabilny trend wzrostowy obserwuje się np. w województwie lubelskim, a w ostatnich latach także w podkarpackim i podlaskim (ryc. 11). 
Ryc. 10. Wartość nakładów inwestycyjnych w małych i średnich firmach w tys. zł na 1 podmiot MŚP (Z5) - Polska Wschodnia na tle kraju w 2012 r.

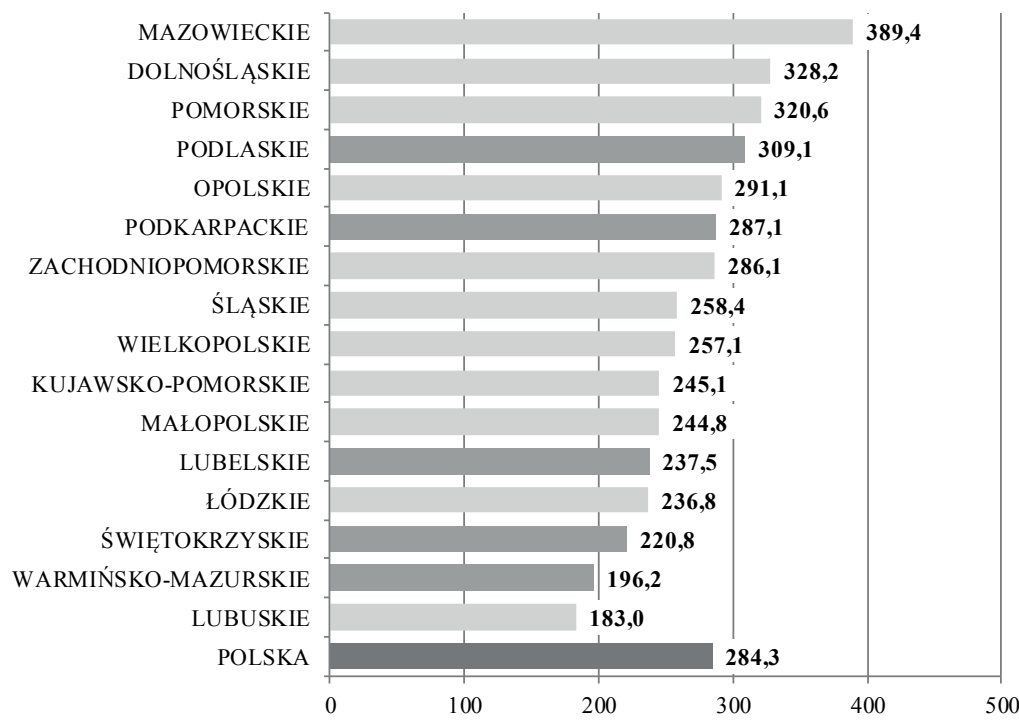

Źródło: opracowanie własne na podstawie GUS.

Ryc. 11. Zmiana wartości nakładów inwestycyjnych w małych i średnich firmach w tys. zł na 1 podmiot MŚP w województwach Polski Wschodniej w stosunku do kraju (rok bazowy: 2003)

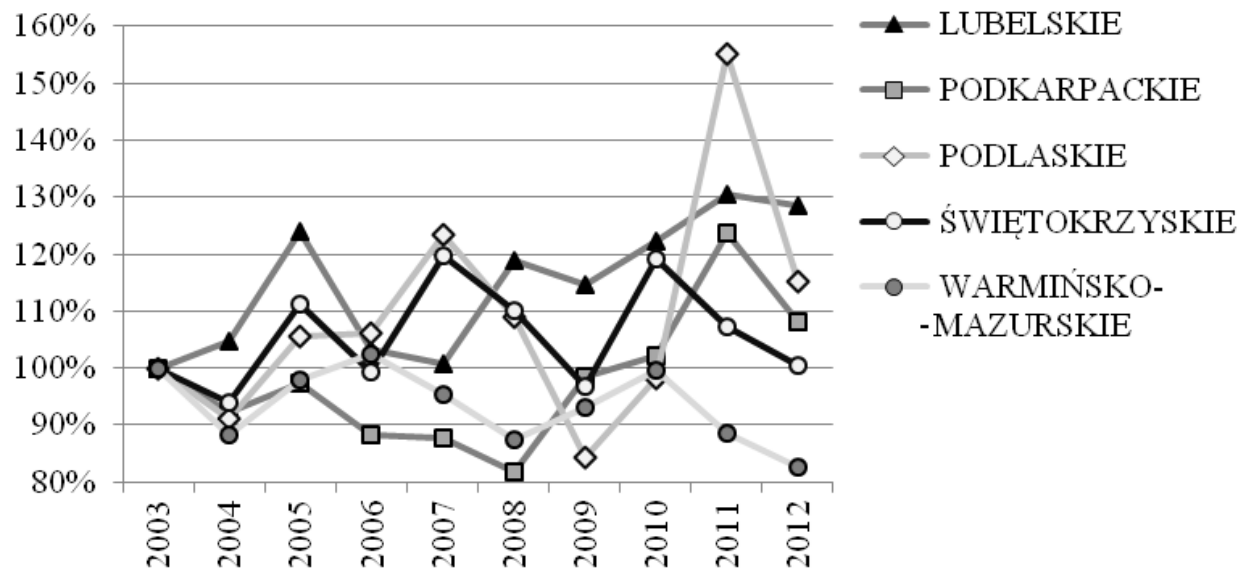

Źródło: opracowanie własne na podstawie GUS.

Ostatni wzięty pod uwagę w niniejszym badaniu miernik potencjału przedsiębiorczego odnosi się do ogólnej aktywności zawodowej danego społeczeństwa. Przyjęto, że im większa jego część jest aktywna zawodowo, tym większa szansa na obserwację przejawów przedsiębiorczości. Społeczności o niskiej aktywności zawodowej charakteryzują się z reguły bardziej 
roszczeniowymi postawami oraz mniejszą chęcią do podejmowania ryzyka związanego z prowadzeniem działalności gospodarczej.

Sytuacja poszczególnych regionów pod względem analizowanego wskaźnika jest dość zróżnicowana. W województwie mazowieckim wskaźnik wynosi 59,7\%, zaś w najsłabszym województwie - warmińsko-mazurskim - 52\% (ryc. 12). Sytuacja w pozostałych województwach Polski Wschodniej prezentują się zdecydowanie lepiej. Najwyższa wartość współczynnika w 2013 r. zanotowana została w regionie lubelskim: 56,6\%.

Ryc. 12. Wartość współczynnika aktywności zawodowej w grupie osób w wieku produkcyjnym (Z6) - Polska Wschodnia na tle kraju w 2013 r.

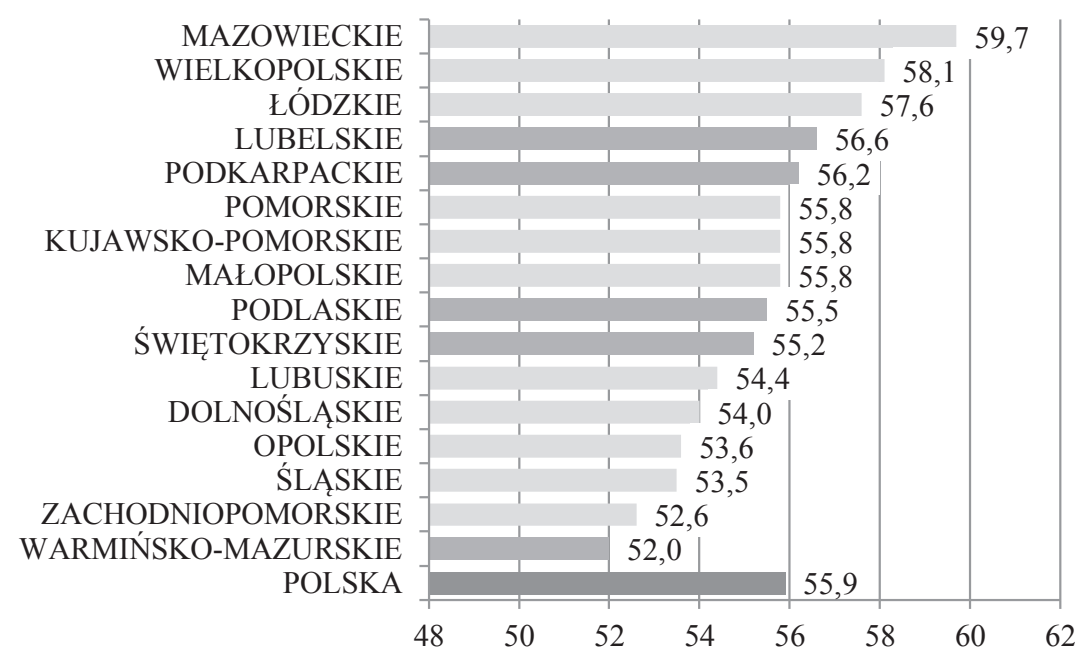

Źródło: opracowanie własne na podstawie GUS.

Analizując relację między średnią wartością współczynnika aktywności zawodowej w Polsce a wartościami notowanymi w poszczególnych województwach, można stwierdzić, że sytuacja części województw Polski Wschodniej w ostatnich latach ustabilizowała się. Natomiast w pozostałych pogarsza się dość wyraźnie (ryc. 13). Do pierwszej grupy należą województwa podkarpackie, lubelskie i świętokrzyskie. Druga obejmuje województwa warmińsko-mazurskie oraz podlaskie. W dwóch ostatnich regionach współczynnik aktywności zawodowej w latach 1999-2013 spadł w stosunku do średniej w kraju o ok. 6-7\%. Pogarsza to znacząco możliwości rozwoju przedsiębiorczości, ograniczając także pozostałe wymiary rozwoju społeczno-gospodarczego. Szczególnie trudną sytuację pod tym względem zaobserwowano w województwie warmińsko-mazurskim, które nie tylko ma najniższy poziom współczynnika w kraju, lecz także jeden z najszybszych spadków jego wartości.

Przedstawiona wyżej analiza wykorzystuje sześć mierników szczegółowych, które służą do oceny porównawczej potencjału przedsiębiorczego. Zbiorcza ocena wymaga zagregowania wyników analizy, doprowadzając do uzyskania informacji zarządczej na poziomie całego wymiaru. W niniejszym artykule zastosowano jeden z najprostszych mechanizmów agregacji, oparty na metodzie unitaryzacji zerowanej (tab. 2). 
Ryc. 13. Zmiana wartości współczynnika aktywności zawodowej w grupie osób w wieku produkcyjnym w województwach Polski Wschodniej w stosunku do kraju (rok bazowy: 1999)

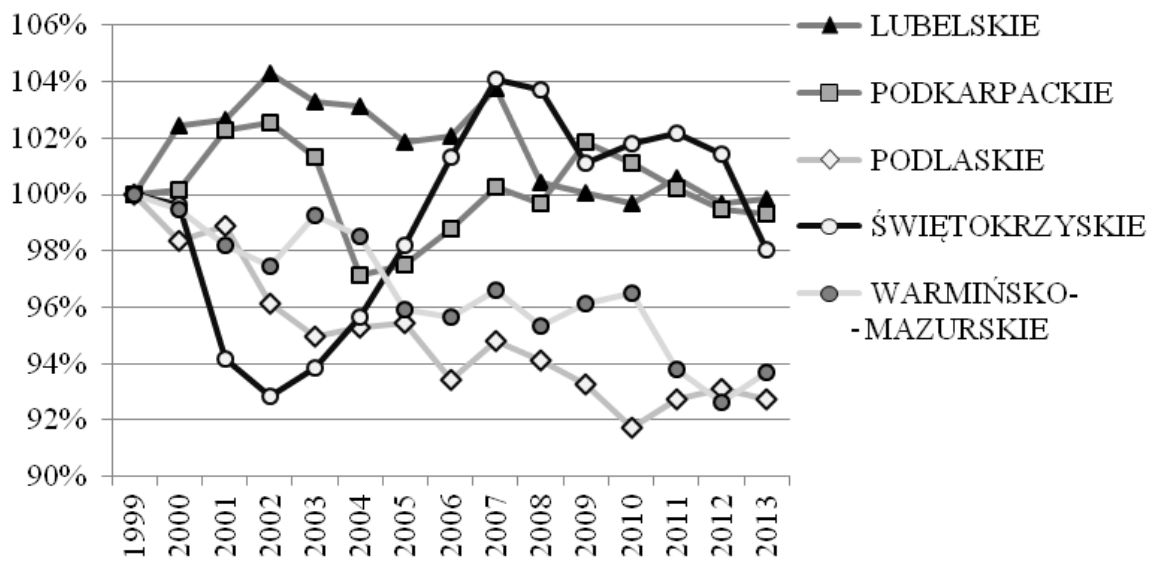

Źródło: opracowanie własne na podstawie GUS.

Tab. 2. Porównanie potencjału przedsiębiorczego w województwach w 2013 r.

\begin{tabular}{|l|c|c|c|c|c|c|c|}
\hline \multicolumn{1}{|c|}{ WOJEWÓDZTWO } & $\mathbf{Z 1}$ & $\mathbf{Z 2}$ & $\mathbf{Z 3}$ & $\mathbf{Z 4}$ & $\mathbf{Z 5}$ & $\mathbf{Z 6}$ & $\mathbf{I 1}$ \\
\hline DOLNOŚLĄSKIE & 0,62 & 0,37 & 0,37 & 0,00 & 0,70 & 0,70 & 0,46 \\
\hline KUJAWSKO-POMORSKIE & 0,30 & 0,18 & 0,07 & 0,64 & 0,30 & 0,30 & 0,30 \\
\hline LUBELSKIE & 0,08 & 0,11 & 0,02 & 0,38 & 0,26 & 0,26 & 0,19 \\
\hline LUBUSKIE & 0,51 & 0,29 & 0,42 & 0,38 & 0,00 & 0,00 & 0,27 \\
\hline ŁÓDZKIE & 0,39 & 0,20 & 0,14 & 0,89 & 0,26 & 0,26 & 0,36 \\
\hline MAŁOPOLSKIE & 0,54 & 0,30 & 0,16 & 0,59 & 0,30 & 0,30 & 0,37 \\
\hline MAZOWIECKIE & 0,93 & 1,00 & 1,00 & 0,39 & 1,00 & 1,00 & 0,89 \\
\hline OPOLSKIE & 0,40 & 0,12 & 0,18 & 0,37 & 0,52 & 0,52 & 0,35 \\
\hline PODKARPACKIE & 0,00 & 0,08 & 0,03 & 0,63 & 0,50 & 0,50 & 0,29 \\
\hline PODLASKIE & 0,15 & 0,06 & 0,02 & 0,25 & 0,61 & 0,61 & 0,28 \\
\hline POMORSKIE & 0,74 & 0,42 & 0,28 & 0,38 & 0,67 & 0,67 & 0,53 \\
\hline ŚLĄSKIE & 0,43 & 0,35 & 0,17 & 1,00 & 0,37 & 0,37 & 0,45 \\
\hline ŚWIĘTOKRZYSKIE & 0,27 & 0,00 & 0,00 & 0,63 & 0,18 & 0,18 & 0,21 \\
\hline WARMIŃSKO-MAZURSKIE & 0,10 & 0,08 & 0,04 & 0,71 & 0,06 & 0,06 & 0,18 \\
\hline WIELKOPOLSKIE & 0,77 & 0,37 & 0,27 & 0,83 & 0,36 & 0,36 & 0,49 \\
\hline ZACHODNIOPOMORSKIE & 1,00 & 0,22 & 0,42 & 0,02 & 0,50 & 0,50 & 0,44 \\
\hline
\end{tabular}

Źródło: opracowanie własne. 
Najpierw dokonano unitaryzacji zmiennych opisujących przedsiębiorczość (Z1-Z6). Na podstawie zunitaryzowanych wartości zmiennych wyliczono indeks zagregowany I1, będący ich średnią arytmetyczną. Przyjęto, że stanowi on ogólną miarę poziomu potencjału przedsiębiorczego badanych regionów. Najwyższym potencjałem przedsiębiorczości charakteryzuje się województwo mazowieckie. Wysoko oceniono także inne rozwinięte regiony - pomorski, wielkopolski, dolnośląski i śląski. Województwa Polski Wschodniej zajmują w rankingu najgorsze pozycje. Najlepiej prezentuje się województwo podkarpackie, zaś najniższy poziom przedsiębiorczości zanotowano w województwie warmińsko-mazurskim.

\section{Podsumowanie i wnioski}

Podsumowując przeprowadzoną analizę, autorzy skupią się na dwóch podstawowych kwestiach: metodologicznej i poznawczej. Pierwsza z nich odnosi się do przedstawionego mechanizmu analizy sytuacji strategicznej regionu. Użyto tutaj modelu potencjału endogenicznego, opisującego cechy regionu. Następnie zastosowano analizę porównawczą z wykorzystaniem danych statystycznych. Dobrano je, uwzględniając zarówno specyfikę poszczególnych wymiarów (np. przedsiębiorczości), jak i możliwości uzyskania danych z ogólnodostępnego systemu statystyki publicznej. Podstawowym problemem z punktu widzenia metodologicznego jest pogodzenie dostępnego zbioru danych $\mathrm{z}$ definicjami wymiarów potencjału endogenicznego.

Operacjonalizacja pojęć, takich jak: przedsiębiorczość, kapitat społeczny, potencjat instytucjonalny, do poziomu zmiennych może być powodem dyskusji i kontrowersji o charakterze teoretycznym. Podstawowe pytanie, które tutaj należy sobie postawić, brzmi: na ile zmienne dostępne w statystyce publicznej rzeczywiście stanowią miarę dla badanego wymiaru. Drugie pytanie dotyczy wag poszczególnych zmiennych w budowaniu indeksu zagregowanego dla danego wymiaru oraz wag wymiaru w budowaniu indeksu ogólnego potencjału endogenicznego. Autorzy zastosowali najprostsze podejście, w którym wykorzystano średnią arytmetyczną. Uzasadnionym wydaje się stosowanie średniej ważonej. Pozostaje jednak kwestia wyznaczenia wartości wag. Tutaj z pomocą przychodzą metody wielokryterialne, np. AHP (Analytic Hierarchy Process) (Saaty, 1990; Prusak, Stefanów, 2014). Pozwala ona dzięki porównywaniu parami wymiarów potencjału, a następnie zmiennych, na uzyskanie wartości ich wag. Eksperci przygotowujący strategię dla danej jednostki terytorialnej mogą w ten sposób dostosować sposób analizy do potrzeb decydentów zarządzających jej rozwojem.

Prezentowane podejście ma potencjał implementacyjny i może być stosowane w analizie strategicznej jednostek terytorialnych, np. regionów. Wartość poznawcza uzyskanego materiału jest duża, zwłaszcza w kontekście ograniczonego stosowania analiz porównawczych w aktualnie istniejących strategiach rozwoju jednostek terytorialnych w Polsce. Porównawcza analiza trendów z wykorzystaniem prostych narzędzi, np. indeksów jednopodstawowych, lub rangowanie z użyciem metod standaryzacji danych tworzy nową przestrzeń decyzyjną. Mając na uwadze potencjalne możliwości implementacyjne prezentowanego podejścia, zaprezentowano nieskomplikowane mechanizmy analizy danych, które nie wymagają stosowania specjalistycznych narzędzi analitycznych. Są także łatwe do zrozumienia dla decydentów, którzy na podstawie uzyskanych danych podejmują decyzje.

Uzyskana ocena regionów Polski Wschodniej pod kątem poziomu potencjału endogenicznego w obszarze przedsiębiorczości jest niska na tle innych regionów w kraju. Relatywnie niewielki poziom przedsiębiorczości, ale też szereg innych strukturalnych problemów tego obszaru, potwierdzają liczne badania (np.: Gorzelak, 2007; Kurek, 2010; Miszczuk i in., 2011; Bański, Pantyley, 2013). Skutkiem tego jest dalsze powstawanie luki rozwojowej między regionami o mocnych centrach wzrostu (np. Mazowsze czy Małopolska) a regionami peryferyjnymi 
(np. Lubelszczyzna, Podlasie). W takiej sytuacji aktywność administracji publicznej powinna być szczególnie intensywna (Malizia, Feser, 1999). Tylko dzięki skutecznej polityce rozwojowej oraz optymalizacji zarządzania operacyjnego na poziomie instytucji administracji publicznej możliwe jest podniesienie poziomu konkurencyjności badanych regionów.

\section{Literatura \\ References}

Aghion, Ph., Howitt, P. (1998). Endogenous Growth Theory. Massachusetts Institute of Technology.

Annoni, P., Dijkastra, L. (2013). EU Regional Competitiveness Index. Luxembourg: European Union.

Bański, J., Pantyley, V. (2013). Warunki życia we wschodniej Polsce wedtug regionów i kategorii jednostek osadniczych. Nierówności spoleczne a wzrost gospodarczy. 34, 107-123.

Burchard-Dziubińska, M. (2007). Ekologiczne determinanty rozwoju gospodarczego. W: R. Piasecki (red.), Ekonomia rozwoju. Warszawa: PWE

Chądzyński, J., Nowakowska, A., Przygodzki, Z. (2007). Region i jego rozwój w warunkach globalizacji. CeDeWu. PL Wydawnictwa Fachowe.

Churski, P. (2004). Rozwój regionalny w warunkach transformacji gospodarczej i integracji europejskiej. W: S. Ciok, D. Ilnicki (red.). Przeksztatcenia regionalnych struktur funkcjonalno-przestrzennych. Regionalny wymiar integracji europejskiej. t. VIII/1, Wrocława: Instytut Geografii i Rozwoju Regionalnego Uniwersytetu Wrocławskiego, 31-45.

Czapiński J., Panek, T. (red.). (2011). Diagnoza społeczna 2011. Warszawa: Rada Monitoringu Społecznego.

Czupiała, J. (1994). Ekonomika innowacji. Wrocław: Wydawnictwo Akademii Ekonomicznej im. Oskara Langego we Wrocławiu.

Gieryszewska, G., Romanowska, M. (1998). Analiza strategiczna przedsiębiorstwa. Warszawa: Polskie Wydawnictwo Ekonomiczne.

Gorzelak, G. (2007). Strategiczne kierunki rozwoju Polski Wschodniej. W: Warunki rozwoju Polski Wschodniej w perspektywie 2020. Warszawa: MRR.

Keeley, B. (2007). Human capital. How what you know shapes your life. OECD.

Kurek, S. (2010). Przestrzenne zróżnicowanie poziomu rozwoju regionalnego w Unii Europejskiej w świetle wybranych mierników. Prace Komisji Geografii Przemystu Polskiego Towarzystwa Geograficznego, $16,87-104$.

Malizia, E.E., Feser, E.J. (1999). Understanding Local Economic Development. Center for Urban Policy Research.

McCann, Ph., Ortega-Argilés, R. (2013). Smart specialization, regional growth and applications to European union cohesion policy. Regional Studies ahead-of-print, 1-12.

Miszczuk, A., Smętkowski, M., Płoszaj, A., Celińska-Janowicz, D. (2011). Aktualne problemy demograficzne Polski Wschodniej. W: Budowanie spójności terytorialnej i przeciwdziałanie marginalizacji obszarów problemowych. Ministerstwo Rozwoju Regionalnego, 96-105.

Pickton, D.W., Wright, S. (1998). What's swot in strategic analysis?. Strategic change, 7, 101-109.

Porter, M.E. (2011). Competitive advantage of nations: creating and sustaining superior performance. Simon and Schuster.

Prusak, A., Stefanow, P. (2014). AHP - analityczny proces hierarchiczny. Warszawa: Wydawnictwo C.H. Beck.

Romer, P.M. (1994). The origins of endogenous growth. The journal of economic perspectives, 3-22.

Rusu, M. (2013). Smart specialization a possible solution to the new global challenges. Procedia Economics and Finance, 6, 128-136.

Saaty, T.L. (1990). How to make a decision: the analytic hierarchy process. European journal of operational research, 48(1), 9-26. 
Sextona, D.L., Smilora, R.W. (red.). (1986). The Art and Science of Entrepreneurship. Cambridge: Ballinger Pub. Comp.

Strategia rozwoju społeczno-gospodarczego Polski Wschodniej do roku 2020. (2008). Rada Ministrów.

Strojny, J. (2012). Innowacyjne zarządzanie regionem, powiatem i gmina. Rzeszów: Politechnika Rzeszowska.

\section{Inne źródła}

www.stat.gov.pl

Jacek Strojny, dr, adiunkt, Politechnika Rzeszowska im. Ignacego Łukasiewicza.

Ekonomista, doktor nauk ekonomicznych w zakresie nauk o zarządzaniu, adiunkt w Katedrze Ekonomii Wydziału Zarządzania Politechniki Rzeszowskiej, Pełnomocnik dziekana ds. projektów rozwojowych i komercjalizacji badań. Specjalizuje się w problematyce implementacji metod i technik zarządzania w przedsiębiorstwach oraz jednostkach administracji publicznej, zarówno na poziomie zarządzania strategicznego, jak i operacyjnego. Jest autorem kilkudziesięciu publikacji dotyczących przedsiębiorczości i innowacji, rozwoju regionalnego i lokalnego oraz zarządzania projektami. Koordynował projekty wdrożenia innowacyjnych systemów zarządzania w kilkudziesięciu przedsiębiorstwach i samorządach. Jest także autorem strategii rozwoju lokalnego na poziomie gminnym i powiatowym.

Jacek Strojny, PhD, Assistant Professor in the Department of Economics, Faculty of Management, Rzeszow University of Technology, The Deans Plenipotentiary for Development and Commercialization. He specializes in methods and techniques implementation in companies and public administration institutions on the strategic and operational level. The author of several dozen publications related to entrepreneurship, innovations, local and regional development and project management as well. He was a coordinator of many innovative implementation projects in companies and public institutions. He is the author of strategic documents prepared on the municipality and district level.

Adres/Address: Politechnika Rzeszowska

al. Powstańców Warszawy 12

35-959, Rzeszów, Polska

e-mail: jstrojny@prz.edu.pl

Michał Kościółek, mgr, Politechnika Rzeszowska im. Ignacego Łukasiewicza.

Studia wyższe ukończył w 2012 r. na Wydziale Ekonomii i Stosunków Międzynarodowych Uniwersytetu Ekonomicznego im. Komisji Edukacji Narodowej w Krakowie. Działalność naukową i dydaktyczną rozpoczął w 2013 r. na Politechnice Rzeszowskiej jako asystent w Katedrze Ekonomii, kierowanej przez dr. hab. Stanisława Gędka, prof. PRz. Główne zainteresowania badawcze autora to przede wszystkim makroekonomia, funkcjonowanie rynku pracy oraz analiza rynków lokalnych i regionalnych.

Michał Kościółek, graduated from the Faculty of Economics and International Relations Higher education in 2012 at the Rzeszow University of Technology as an assistant in the Department of Economics, led by Professor Stanisław Gędek. The main research interests of the author is primarily macroeconomics, labor market functioning and analysis of local and regional markets.

Adres/Address: Politechnika Rzeszowska

al. Powstańców Warszawy 12

35-959, Rzeszów, Polska

e-mail:mkos@prz.edu.pl 